\title{
MUTU SEKOLAH PADA SEKOLAH DASAR DITINJAU DARI SUPERVISI KEPALA SEKOLAH DAN MANAJEMEN KELAS
}

\author{
Ruhita $^{1}$ \\ ${ }^{1}$ Universitas Wiralodra, Jln.Ir.H. Juanda Km 3 Indramayu, ruhita_pasca@unwir.ac.id
}

\begin{abstract}
ABSTRAK
Penelitian ini bertujuan untuk melihat mutu sekolah dasar yang ada di Kecamatan Sindang ditinjau dari Supervisi yang dilakukan kepala sekolah dan manjemen pengelolaan kelas. Penelitian ini dilaksanakan di Sekolah Dasar Negeri di Kecamatan Sindang Kabupaten Indramayu dengan populasi penelitian yaitu seluruh guru SD yang berstatus PNS sejumlah 196 orang di lingkungan UPTD Kecamatan Sindang Kabupaten Indramayu. Secara ringkas teknik analisis yang digunakan dalam penelitian ini adalah analisis korelasi Pearson Product Moment dan korelasi ganda, yang dilanjutkan dengan analisis regresi. Berdasarkan hasil penelitian disimpulkan (1) Supervisi yang dilakukan kepala sekolah memiliki kontribusi 44,5 \% terhadap mutu sekolah; (2) Optimalisasi pengelolaan kelas yang baik berkontribusi sebesar $47,5 \%$ terhadap mutu sekolah; (3) untuk mutu sekolah jika ditinjau dari supervisi dan manajemen kelas secara bersama sama ketika dilakukan sebesar $61,1 \%$. Saran penelitian ini kepala sekolah sebagai pimpinan tertinggi dalam jenjang sekolah harus terus melakukan proses supervisi dan mengoptimalisasikan manjemen kelas dengan baik.
\end{abstract}

Kata kunci: Supervisi Kepala Sekolah, Manajemen Kelas, Mutu Sekolah.

\section{PENDAHULUAN}

Mutu pendidikan khususnya di Sekolah Dasar (SD) memiliki peran yang cukup besar dalam mencapai tujuan nasional pendidikan. Tujuan pendidikan di SD dalam aspek pelaksanaannya berbentuk bimbingan secara terpadu dan mengarahkan siswa untuk mencapai perubahan tingkah laku dan pemahaman menjadi lebih baik. Menurut Dwi Siswoyo dkk. (Kompri, 2015:16) pendidikan sebagai usaha sadar bagi pengembangan manusia dan masyarakat, mendasarkan pada landasan pemikiran tertentu.

Berdasarkan permasalahan mutu pada sekolah di Kecamatan Indramayu menjadi sesuatu yang sangat penting, karena ternyata masih banyak sekolah yang kekurangan tenaga pengajar profesional terlihat dari jumlah guru PNS yang bersertifikasi, siswa yang mengikuti lomba-lomba di tingkat provinsi dan nasional masih didominasi dari Kecamatan lain, dan sarana prasarana yang ada di tiap sekolah masih belum memadai. Sebagai salah satu pertimbangan maka peneliti memaparkan beberapa fakta di lapangan (data didapat dari Dinas Pendidikan Kabupaten Indramayu) untuk kecamatan Sindang sebagai berikut :

1. Dari segi prestasi akademik, untuk lomba Calistung kelas I Kecamatan Sindang masuk peringkat ke 15 sementara yang peringkat pertama dari Kecamatan Haurgeulis, 
Calistung Kelas II Kecamatan Sindang masuk peringkat ke 12 sementara yang peringkat pertama dari Kecamatan Indramayu, dan Calistung Kelas III masuk peringkat ke 4 sementara yang peringkat pertama dari Kecamatan Indramayu. Untuk lomba MIPA, Kecamatan Sindang IPA masuk peringkat ke 27 sementara yang peringkat pertama dari Kecamatan Karangampel, Matematika Kecamatan Sindang masuk peringkat ke 30 sementara yang peringkat pertama dari Kecamatan Karangampel.

2. Untuk Nilai Ujian Sekolah Kecamatan Sindang masuk ke urutan ke 20 dengan nilai rata-rata US Bahasa Indonesia 74,29, nilai rata-rata US Matematika 73,56, dan nilai rata-rata US 73,79

3. Untuk Jumlah lulusan Kecamatan Sindang pada tahun 2014/2015 sebanyak 817 siswa dan pada tahun 2015/2016 sebanyak 788 siswa.

Jika dilihat dari proses pendidikan, peranan kepala sekolah dalam hal supervisi memegang peranan yang sangat penting. Situmorang dan Juhir (2001) menyatakan bahwa pengawasan/ supervisi dilakukan untuk: (1) Mengetahui jalannya pekerjaan, apakah berjalan lancar atau tidak; (2) Memperbaiki kesalahan yang dibuat oleh pegawai dan melakukan tindakan pencegahan agar tidak terulang kembali kesalahan tersebut atau mencegah timbulnya kesalahan yang baru; (3) Mengetahui apakah penggunaan anggaran yang telah ditetapkan sesuai dengan rencana yang telah ditentukan; (4) Mengetahui pelaksanaan kerja sesuai dengan program yang direncanakan; (5) Mengetahui hasil pekerjaan dibandingkan dengan rencana atau standar yang telah ditetapkan.

Selain Supervisi yang dilakukan oleh kepala sekolah ada aspek lain yang penting yang berpengaruh terhadap keberhasilan pendidikan salah satunya terletak pada kualitas guru. Mengingat peran guru yang besar dalam proses pendidikan, kepala sekolah sebagai atasan langsung dituntut memiliki kapasitas utama sebagai edukator, manajer, administrator, supervisor, leader, inovator, dan motivator. Guru memiliki fungsi sebagai educator, fasilitator dan motivator bagi siswa. Penelitian ini memfokuskan pada bagaimana guru melakukan manajemen kelas dengan baik sehingga proses pembelajaran dapat berjalan sesuai harapan.

Peranan manajemen kelas yang dilakukan guru nampaknya masih kurang mampu membuat pendidikan bermutu tinggi. Manajemen kelas yang dinamis meliputi : (1) Berbagai jenis kelas, (2) Belajar bersama dalam kelompok, (3) Mengadakan analisis sosial, (4) Mengefektifkan papan tulis dikelas, (5) Mengefektifkan posisii tempat duduk siswa, (6) 
Mengembangkan pemetaan bahan, (7) Memanfaatkan perpustakaan sekolah, (8) Mengembangkan kemampuan bertanya, (9) Mengatasi masalah disiplin di kelas.

Berdasarkan hal tersebut maka peneliti tertarik untuk melakukan pengkajian berkaitan dengan pengaruh supervisi kepala sekolah dan manajemen kelas secara bersama-sama (simultan) terhadap mutu sekolah pada SD di Kecamatan Sindang Kabupaten Indramayu.

\section{METODE PENELITIAN}

Penelitian ini dilaksanakan di Sekolah Dasar Negeri di Kecamatan Sindang Kabupaten Indramayu dengan populasi penelitian ini merupakan populasi homogen yaitu seluruh guru SD yang berstatus PNS sejumlah 196 orang di lingkungan UPTD Kecamatan Sindang Kabupaten Indramayu. Indikator variabel supervisi kepala sekolah yang meliputi : (1) Supervisi yang bersifat korektif (corrective supervision), (2) Supervisi yang bersifat preventif (preventive supervision), (3) Supervisi yang bersifat konstruktif (constructive supervision), (4) Supervisi yang bersifat kreatif (creative supervision) (Gagne, R.M and Briggs, 1992). Indikator variabel manajemen kelas, yang meliputi : (1) perencanaan (planning), (2) pengorganisasian (organizing), (3) penggerakkan (actuating), (4) pengawasan (controlling) (Mulyasa, 2002:7). Indikator mutu sekolah yang meliputi : (1) aspek individu murid, (2) Kurikulum, (3) guru, (4) lulusan (M. Fantini dalam Tobroni, 2010).

Dalam penelitian ini Teknik instrumen yang digunakan adalah studi kepustakaan, observasi atau pengamatan dan Penyebaran angket. Analisis data yang digunakan dalam penelitian ini adalah uji validitas dengan analisis faktor, setelah semua data valid maka dilanjutkan dengan pengujian reabilitas menggunakan rumus "alpha" Spearman Brown. Secara ringkas teknik analisis yang digunakan dalam penelitian ini adalah analisis korelasi Pearson Product Moment dan korelasi ganda, yang dilanjutkan dengan analisis regresi.

\section{HASIL DAN PEMBAHASAN}

Hasil penelitian memberikan gambaran data dari tiap dimensi pada variabel supervisi kepala sekolah tersebut, terlihat besarnya rata-rata nilai tanggapan responden secara umum sebesar 3,85. Pada dimensi korektif mendapat nilai rata-rata terendah yaitu sebesar 3,80 dan nilai yang tertinggi pada dimensi kreatif sebesar 3,91. Dengan merujuk pada kriteria Waighted Means Scored, kecenderungan data korektif ini dikategorikan "tinggi”. 
Supervisi kepala sekolah di lingkungan SD Negeri di Kecamatan Sindang Kabupaten Indramayu tergolong dalam kondisi baik, hal ini terlihat dari dimensi-dimensi subjek penelitian yang mencapai 3,8 untuk dimensi korektif; preventif 3,84; konstruktif 3,87 dan kreatif 3,91. Nilai rata-rata untuk dimensi korektif dikategorikan "cukup" yaitu sebesar 3,85 .

Dari hasil gambaran pengolahan data dari tiap dimensi pada variabel manajemen kelas tersebut, terlihat besarnya rata-rata nilai tanggapan responden secara umum sebesar 4,06. Nilai rata-rata tertinggi ada pada dimensi pengawasan yaitu sebesar 4,13 sedangkan nilai rata-rata terendah ada pada dimensi perencanaan. Dengan merujuk pada kriteria Waighted Means Scored (WMS), gambaran kondisi manajemen kelas pada Sekolah Dasardi Kecamatan Sindang Kabupaten Indramayu menunjukkan bahwa pada umumnya dikategorikan "tinggi".

Hasil pengolahan gambaran data dari tiap dimensi pada variabel mutu sekolah (tersebut, terlihat besarnya rata-rata nilai tanggapan responden secara umum sebesar 4,12.Nilai rata-rata tertinggi ada pada dimensi aspek pribadi murid yaitu sebesar 4,17 sedangkan nilai rata-rata terendah ada pada dimensi kurikulum 4,03. Dengan merujuk pada kriteria Waighted Means Scored (WMS), data variabel mutu sekolah ini dikategorikan "tinggi".

Berdasarkan hasil pengolahan uji normalitas didapat distribusi data ketiga variabel tersebut secara keseluruhan diperlihatkan pada tabel berikut.

\section{Tabel 1}

Normalitas Data Variabel Penelitian

\begin{tabular}{cccc}
\hline Variabel & Nilai & Nilai & Sifat Distribusi \\
& Probabilitas & $\boldsymbol{\alpha}$ & Data \\
\hline Supervisi Kepala Sekolah $\left(\mathbf{X}_{\mathbf{1}}\right)$ & 0,303 & 0,05 & normal \\
Manajemen Kelas $\left(\mathbf{X}_{2}\right)$ & 0,192 & 0,05 & normal \\
Mutu Sekolah $(\mathbf{Y})$ & 0,610 & 0,05 & normal \\
\hline
\end{tabular}

Berdasarkan tabel diatas dengan menggunakan $\boldsymbol{\alpha}=0,05$ didapat bahwa variabel berdistribusi normal dengan nilai probabilitas 0,303 , variabel berdistribusi normal dengan nilai probabilitas 0,192, dan variable (Y) berdistribusi normal dengan nilai probabilitas 0,610 . 
Berdasarkan hasil pengoahan uji linieritas antara variabel supervisi kepala sekolah dengan variabel mutu sekolah didapat rekapitulasi hasil uji linieritas sebagaimana berikut:

\section{Tabel 2}

Rekapitulasi Hasil Uji Linieritas

\begin{tabular}{ccccc}
\hline No & Variabel & Linearity & Signifikansi & Simpulan \\
\hline $\mathbf{1}$ & $\mathrm{X}_{1}$ atas $\mathrm{Y}$ & 0.077 & 0.05 & Linier \\
$\mathbf{2}$ & $\mathrm{X}_{2}$ atas $\mathrm{Y}$ & 0.062 & 0.05 & Linier \\
\hline
\end{tabular}

Berdasarkan tabel di atas dapat diketahui bahwa data pada variabel terikat mempunyai linieritas dengan data pada masing-masing variabel bebas. Hasil ini memberikan makna bahwa pengolahan data memungkinkan dilanjutkan dengan menggunakan regresi.

Berdasarkan hasil penelitian jika dilihat keterkaitan antara supervisi dengan mutu sekolah dapat diketahui besarnya determinasi variabel supervisi kepala sekolah terhadap variabel mutu sekolah adalah sebesar 0,445 atau 44,5\%. Artinya mutu sekolah dipengaruhi oleh variabel supervisi kepala sekolahsebesar $44,5 \%$, sedangkan sisanya dipengaruhi oleh faktor lain. Untuk keterkaitan antara variabel manajemen kelas dengan mutu sekolah dapat diketahui besarnya koefisien determinasi variabel manajemen kelas terhadap variabel mutu sekolah adalah sebesar 0,475 atau 47,5\%. Untuk mutu sekolah jika ditinjau berdasarkan variabel supervisi dan manajemen kelas memberikan kontribusi sebesar 0,611 atau 61,1\%. Artinya mutu sekolah dipengaruhi oleh variabel supervisi kepala sekolah dan variabel manajemen kelas secara bersama-sama sebesar $61,1 \%$, sedangkan sisanya dipengaruhi oleh faktor lain.

\section{PENUTUP}

Berdasarkan hasil penelitian disimpulkan (1) Supervisi yang dilakukan kepala sekolah memiliki kontribusi 44,5\% terhadap mutu sekolah; (2) Optimalisasi pengelolaan kelas yang baik berkontribusi sebesar 47,5\% terhadap mutu sekolah; (3) untuk mutu sekolah jika ditinjau dari supervisi dan manajemen kelas secara bersama sama ketika dilakukan sebesar $61,1 \%$. Saran penelitian ini kepala sekolah sebagai pimpinan tertinggi dalam jenjang sekolah harus terus melakukan proses supervisi dan mengoptimalisasikan manjemen kelas dengan baik. 


\section{UCAPAN TERIMAKASIH}

Terimkasih kepada semua pihak yang telah membantu penulisan karya ilmiah ini.

\section{DAFTAR PUSTAKA}

A.Mulyasa. (2002). Manajemen berbasis Sekolah, Konsep Strategi dan Implementasi. Bandung: Remaja Rosdakarya.

Gagne, R.M and Briggs.(1992). Principles of Intructional Design. New York: Hill Book Company

M. Situmorang, Viktor dan Juhir. (2001). Aspek Hukum Pengawasan Melekat Dalam Lingkungan Aparatur Negara. Jakarta : PT. Rineka Cipta

Siswoyo, Dwi, et al. (2011). Ilmu Pendidikan. Yogyakarta: UNY Press

Tobroni. (2010). Spiritual Leadership The Probem Solver, Krisis Kepemimpinan Dalam Pendidikan Islam.http://tobroni.staff.umm.ac.id/2010/11/29/spiritual-leadershipthe-problem-solver-krisis-kepemimpinan-dalam-pendidikan-islam. Diunduh 10 Maret 2014 